Article

\title{
Fabrication and Characterization of Nanoporous Niobia, and Nanotubular Tantala, Titania and Zirconia via Anodization
}

\author{
Sepideh Minagar ${ }^{1}$, Christopher C. Berndt ${ }^{1,2}$ and Cuie Wen ${ }^{1,3, *}$
}

1 Faculty of Science, Engineering and Technology, Swinburne University of Technology, Hawthorn, Victoria 3122, Australia; E-Mails: sminagar@swin.edu.au (S.M.); cberndt@swin.edu.au (C.B.)

2 Department of Materials Science and Engineering, Stony Brook University, Stony Brook, New York, NY 11794, USA

3 School of Aerospace, Mechanical and Manufacturing Engineering, RMIT University, Bundoora, Victoria 3083, Australia

* Author to whom correspondence should be addressed; E-Mail: cuie.wen@rmit.edu.au; Tel.: +61-3-9925-7290; Fax: +61-3-9925-6108.

Academic Editor: Antonella Sola

Received: 19 December 2014 / Accepted: 24 March 2015 / Published: 31 March 2015

\begin{abstract}
Valve metals such as titanium (Ti), zirconium ( $\mathrm{Zr})$, niobium $(\mathrm{Nb})$ and tantalum $(\mathrm{Ta})$ that confer a stable oxide layer on their surfaces are commonly used as implant materials or alloying elements for titanium-based implants, due to their exceptional high corrosion resistance and excellent biocompatibility. The aim of this study was to investigate the bioactivity of the nanostructures of tantala $\left(\mathrm{Ta}_{2} \mathrm{O}_{5}\right)$, niobia $\left(\mathrm{Nb}_{2} \mathrm{O}_{5}\right)$, zirconia $\left(\mathrm{ZrO}_{2}\right)$ and titania $\left(\mathrm{TiO}_{2}\right)$ in accordance to their roughness and wettability. Therefore, four kinds of metal oxide nanoporous and nanotubular $\mathrm{Ta}_{2} \mathrm{O}_{5}, \mathrm{Nb}_{2} \mathrm{O}_{5}, \mathrm{ZrO}_{2}$ and $\mathrm{TiO}_{2}$ were fabricated via anodization. The nanosize distribution, morphology and the physical and chemical properties of the nanolayers and their surface energies and bioactivities were investigated using SEM-EDS, X-ray diffraction (XRD) analysis and 3D profilometer. It was found that the nanoporous $\mathrm{Ta}_{2} \mathrm{O}_{5}$ exhibited an irregular porous structure, high roughness and high surface energy as compared to bare tantalum metal; and exhibited the most superior bioactivity after annealing among the four kinds of nanoporous structures. The nanoporous $\mathrm{Nb}_{2} \mathrm{O}_{5}$ showed a uniform porous structure and low roughness, but no bioactivity before annealing. Overall, the nanoporous and nanotubular layers of $\mathrm{Ta}_{2} \mathrm{O}_{5}, \mathrm{Nb}_{2} \mathrm{O}_{5}, \mathrm{ZrO}_{2}$ and $\mathrm{TiO}_{2}$ demonstrated
\end{abstract}


promising potential for enhanced bioactivity to improve their biomedical application alone or to improve the usage in other biocompatible metal implants.

Keywords: nanotube; tantala; niobia; zirconia; titania; wettability; roughness; hydroxyapatite

\section{Introduction}

Metals and alloys that are used as biomaterials also have a range of applications in industry and medicine due to their excellent mechanical, physical and chemical properties. Extensive studies have been carried out on titanium that has been coated by its natural oxide layer formed in air. Other biocompatible metals and their respective oxide layers are also of interest. For example, the protective oxide layer that forms naturally on a tantalum surface or that is fabricated on the surface of other metals by surface treatments such as chemical vapor deposition [1], electro deposition [2,3] and sol gel [4] methods have other applications. Tantalum pentoxide, $\mathrm{Ta}_{2} \mathrm{O}_{5}$, is used as a protective coating for chemical equipment due to its excellent corrosion resistance [1]. A thin film of $\mathrm{Ta}_{2} \mathrm{O}_{5}$, formed by radio frequency (RF) sputtering of $\mathrm{SiO}_{2}-\mathrm{Ta}_{2} \mathrm{O}_{5}$ films, has been used in optical devices and memory devices [5]. The biocompatibility of the tantalum pentoxide layer suggests tantalum as a good candidate for bioengineering implant applications [6]. By anodization a nanoporous $\mathrm{Ta}_{2} \mathrm{O}_{5}$ can be formed on the metal in an acidic electrolyte containing hydrofluoric acid (HF) [7-9]. The organic electrolytes were also used for anodizing a nanoporous $\mathrm{Ta}_{2} \mathrm{O}_{5}$ layer at an applied potential of $10-40 \mathrm{~V}[10,11]$.

The application of niobium pentoxide $\left(\mathrm{Nb}_{2} \mathrm{O}_{5}\right)$, which can be produced via different methods, such as reactive sputtering [12], sol-gel processes [13], templating techniques [14] and anodic oxidation [15,16], has been reported in applications for gas sensors [17], catalysts [18], both optical and electrochromic devices [12], solid state electrochemical devices [19] and biocompatible prostheses [13]. There are studies on the formation of a nanoporous layer of $\mathrm{Nb}_{2} \mathrm{O}_{5}$ by controlling the effects of mixed electrolytes, applied potential and anodization time. These nanoporous layers displayed different range of pore sizes and thickness formed mostly in an acidic electrolyte [15,20,21]. An important application for zirconium dioxide $\left(\mathrm{ZrO}_{2}\right)$ is as an industrial catalyst, especially with its use as an acid catalyst and for $\mathrm{NO}_{x}$ reduction because it is more stable under hydrothermal conditions in comparison to zeolites. This metal oxide also exhibits large pores and a flexible mix in metal oxide composition [22,23]. Zirconia, $\mathrm{ZrO}_{2}$, can have optoelectronic and biomedical applications due to its high mechanical, chemical, and thermal stability [24]. The formation of self-organized sponge-like porous $\mathrm{ZrO}_{2}$ [25] and nanotube oxide layer with different nanoscale sizes and thicknesses [26] has been described in detail along with the effect of changing the condition of electrolyte, applied potential and time of anodization [26-30].

The composition of the substantial mineral form of hard tissue such as bone and dentin is apatite, which is secreted by bone cells on the implant surface during the process of attachment. The bioactive materials, which contained $\mathrm{Si}-\mathrm{OH}, \mathrm{Ti}-\mathrm{OH}, \mathrm{Zr}-\mathrm{OH}, \mathrm{Nb}-\mathrm{OH}$ and $\mathrm{Ta}-\mathrm{OH}$, have been reported to exhibit the ability to induce apatite formation [31]. The effect of Ta-OH groups on the surface of alkaline treated bioactive tantalum metal to form bone like apatite was investigated and the $\mathrm{Ca} / \mathrm{P}$ ratio of 1.59 was reported for crystalline apatite after immersing in simulated body fluid (SBF) [32]. The nanoporous niobium oxides, which were prepared by sol-gel method and coated on 316LSS enhanced hydroxyapatite 
formation [33]. Nanosheets and nanofiber-like surface formed on niobium surface by hydrothermal alkaline treatment significantly influenced its apatite inducing ability [34]. The porous tantalum coating surface was reported to enhance osseoinductivity in vitro and promote new bone formation in vivo [35]. Amorphous nanoporous bioactive sodium niobate hydrogel layer formed on the surface of niobium by alkaline treatment induced the deposition of a CaP layer during soaking in SBF [36]. As formed $\mathrm{ZrO}_{2}$ nanotubes have been reported to induce apatite formation [37], and annealing improved its bioactivity [38]. Using pre-treatment, such as effective dipping treatment, improved bioactivity of as formed $\mathrm{ZrO}_{2}$ nanotube with diameter 35 to $80 \mathrm{~nm}$ [39]. The osseointegration was observed for the anodized surface of zirconium implanted in Wistar rats [40]. Although a few studies have investigated the bioactivity of $\mathrm{ZrO}_{2}$ nanotubes, there is still a lack of research in this aspect for nanoporous $\mathrm{Nb}_{2} \mathrm{O}_{5}$ and $\mathrm{Ta}_{2} \mathrm{O}_{5}$, which is the object of this study.

In this study, a close observation has been carried out on the relationship between the nanoporous and nanotubular characteristics of $\mathrm{Ta}_{2} \mathrm{O}_{5}, \mathrm{Nb}_{2} \mathrm{O}_{5}, \mathrm{ZrO}_{2}$ and $\mathrm{TiO}_{2}$ such as roughness, wettability and surface energy and the bioactivity. The bioactive property of the surface layers is important in terms of the biomedical applications of these biocompatible metals. However, there are insufficient studies in this aspect, to date. The prime motivation for the current work is to elucidate the influence of the nano characteristics of the surface layer on the bioactivity of the substrate metals.

\section{Results and Discussion}

\subsection{The Dynamics of the Anodization Process for Tantala $\left(\mathrm{Ta}_{2} \mathrm{O}_{5}\right)$, Niobia $\left(\mathrm{Nb}_{2} \mathrm{O}_{5}\right)$ and $\mathrm{Zirconia}\left(\mathrm{ZrO}_{2}\right)$}

Figures $1 \mathrm{a}$ and $2 \mathrm{a}$ show a top view of a nanoporous $\mathrm{Ta}_{2} \mathrm{O}_{5}$ that exhibits irregularly distributed pores with a diameter range of $35-65 \mathrm{~nm}$. The thickness of this layer was $1.17 \pm 0.05 \mu \mathrm{m}$, taking note that the sub-structure revealed multiple layers (Figures $1 b$ and 2b), as reported previously [11], where every layer exhibited a closed bottom. Figure 1c shows the cross section of the multiple layers and the arrow indicates $\mathrm{Ta}_{2} \mathrm{O}_{5}$ nanotubes with a length of nearly $152 \pm 1 \mathrm{~nm}$ that formed initially after several seconds during anodization. These long nanotubes transformed into nanoporosity after several seconds during anodization and exhibited similar morphological features to other layers. A top view of the multiple layers can be observed in Figure 1d.

Similar to the anodization of $\mathrm{Ti}$ as described previously [41], the anodization of $\mathrm{Ta}, \mathrm{Nb}$ and $\mathrm{Zr}$ in the presence of $\mathrm{F}^{-}$was observed in three steps: (i) formation of compact and protective metal oxide with a decay of current density ( $v s$. time); (ii) chemical dissolution of the oxide in the presence of the fluoride anion and formation of metal oxide simultaneously with a rise of current density (vs. time); and (iii) reaching equilibrium between oxidation and dissolution with a steady state of current density (vs. time). The anodization conditions, such as applied potential and concentration of $\mathrm{F}^{-}$, were reported to have an influence on the shape of current density $v$ s. time curve $[7,8,15,20,25,26]$. When anodization starts, a compact oxide layer forms on the surface of tantalum for a finite thickness according to the decay characteristics of the current. Tantalum ions, $\mathrm{Ta}^{5+}$, arrive at the interface of the oxide layer and electrolyte and become soluble in the electrolyte by forming $\left[\mathrm{TaF}_{7}\right]^{2-}$. Thus, pores formed at the interface between the oxide layer and electrolyte. These pores continued to develop during anodization because they 
preferred sites that trap the necessary ions. Then, the growth rate of the metal oxide nanoporous and nanotubes may be determined by the diffusion rate of $\mathrm{F}^{-}$ions and the soluble metal complex [42].

Although the formation mechanism for the nanoporosity of tantalum and other valve metals is uncertain, the nanoporosity could be related to the molecular dimension of $\left[\mathrm{TaF}_{7}\right]^{2-}$ and the formation kinetics of $\mathrm{Ta}_{2} \mathrm{O}_{5}$. The standard electrode potential of $\mathrm{Ta} \rightarrow \mathrm{Ta}^{5+}$ is $0.75 \mathrm{~V}$, which is less than that of $\mathrm{Ti} \rightarrow \mathrm{Ti}^{4+}, 2.132 \mathrm{~V}$ [43]. Thus, $\mathrm{Ta}^{5+}$ oxidizes quickly. In addition, the standard enthalpies of formation for $\mathrm{Ta}_{2} \mathrm{O}_{5}$ and $\mathrm{TiO}_{2}$ are -492.790 and -228.360 gram calories per mole, respectively [44]. It can be concluded that the oxidization process and the formation of a $\mathrm{Ta}_{2} \mathrm{O}_{5}$ layer on tantalum are faster than the processes on the titanium surface.

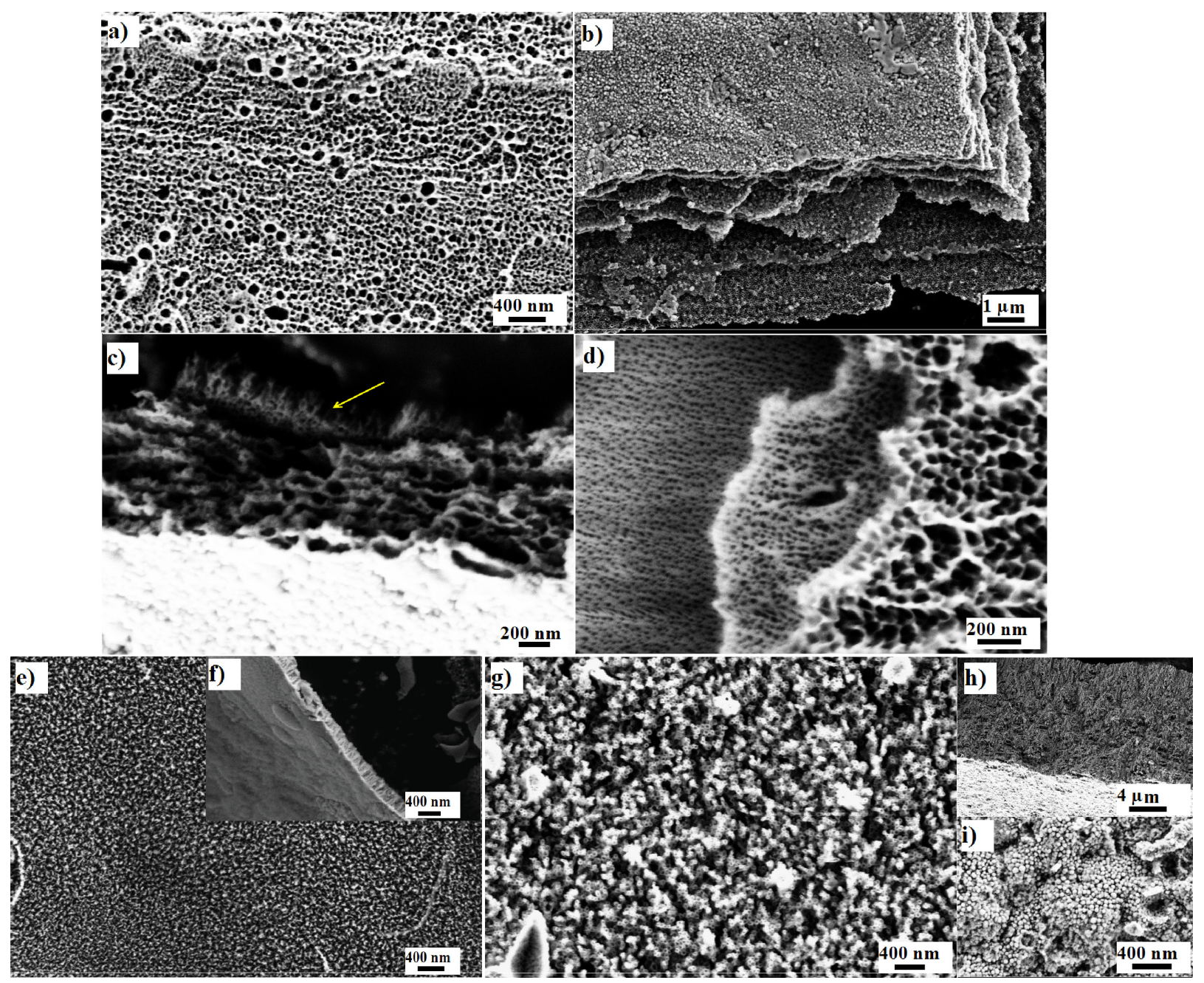

Figure 1. SEM image of nanoporous $\mathrm{Ta}_{2} \mathrm{O}_{5}$ : (a) top view; (b) the bottom view and the cross section of multilayer; (c) shorted life nanotubes (arrow); (d) the top view of multilayer formed on a Ta after anodization for $120 \mathrm{~min}$ in $1 \mathrm{M} \mathrm{H}_{2} \mathrm{SO}_{4}+3.3 \mathrm{wt} \% \mathrm{NH}_{4} \mathrm{~F}, 20 \mathrm{~V}$, SEM image of nanoporous $\mathrm{Nb}_{2} \mathrm{O}_{5}$; (e) top view and (f) cross section formed on niobium after anodization for $16 \mathrm{~min}$ in $1 \mathrm{M} \mathrm{H}_{2} \mathrm{SO}_{4}+3.3 \mathrm{wt} \% \mathrm{NH}_{4} \mathrm{~F}, 20 \mathrm{~V}$ and SEM image of $\mathrm{ZrO}_{2}$ nanotubes (g) top view; (h) cross section and (i) bottom view formed on a zirconium after anodization for $95 \mathrm{~min}$ in $1 \mathrm{M}\left(\mathrm{NH}_{4}\right)_{2} \mathrm{SO}_{4}+0.3 \mathrm{wt} \% \mathrm{NH}_{4} \mathrm{~F}, \mathrm{pH}=5$ and $20 \mathrm{~V}$. 


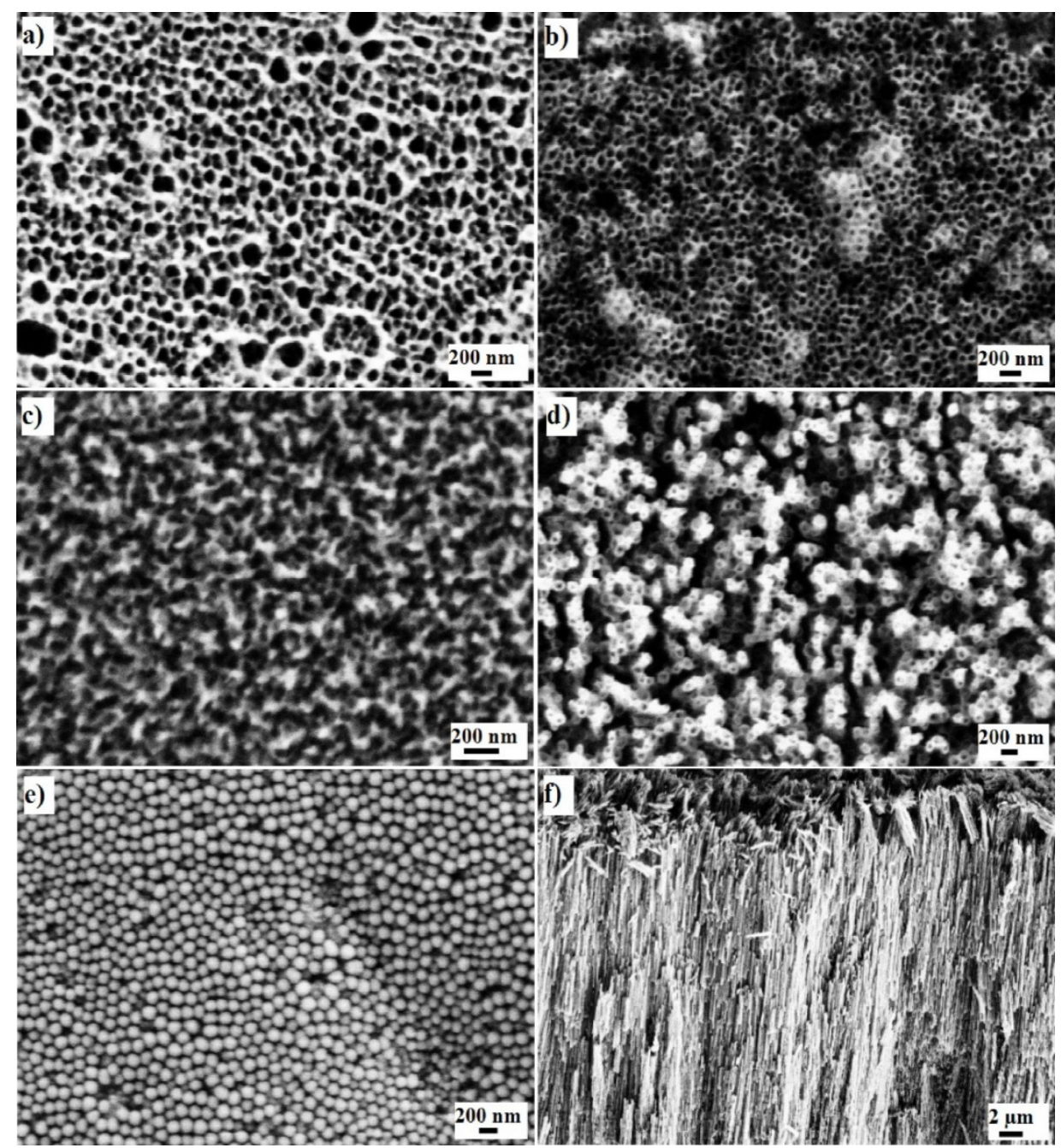

Figure 2. SEM images of nanoporous $\mathrm{Ta}_{2} \mathrm{O}_{5}$ : (a) top view; (b) the middle of the layer; (c) nanoporous $\mathrm{Nb}_{2} \mathrm{O}_{5}$; (d) top view; (e) bottom view; (f) cross section of $\mathrm{ZrO}_{2}$ nanotubes.

The mechanism and kinetics for the oxide layer formation can be calculated on the basis of the ionic radii for $\mathrm{Ta}^{5+}$ and $\mathrm{F}^{-}$on a first principles basis. In this instance, the physical and chemical environment around the $\left[\mathrm{TaF}_{7}\right]^{2-}$ at the pore sites, which affect the molecular size of $\left[\mathrm{TaF}_{7}\right]^{2-}$, are ignored. The structure of the complex has been reported to be a two pentagonal pyramid. The volume of the circumscribed sphere of this structure can be calculated as $26.094 \times 10^{-30} \mathrm{~m}^{3}$, which is smaller than the octahedral volume of $\left[\mathrm{TiF}_{6}\right]^{2-}=29.182 \times 10^{-30} \mathrm{~m}^{3}$. It can be expected that the diffusion of $\left[\mathrm{TaF}_{7}\right]^{2-}$ is faster than $\left[\mathrm{TiF}_{6}\right]^{2-}$ and that the pore growth does not occur solely at the bottom, but also at the walls, thereby resulting in pores that merge and agglomerate. Over a period of several seconds, the pore was bottle-shaped, similar to that of nanotubes with a closed bottom where the diameter of tubes near the bottom was greater than that at the tube necks. Gaps are also created at the bottom of the layer when the pores merged, which permits the electrolyte to become available underneath the nanotubes. Thus, a new layer of nanotubes can form under the same mechanism, thereby resulting in the formation of multilayers of nanoporous layer over time. The nanotubes dissolve according to the dissolution rate of the oxide layer in the presence of the fluorine ions $\left(\mathrm{F}^{-}\right)$.

The nanoporous $\mathrm{Nb}_{2} \mathrm{O}_{5}$ (as shown in Figures 1e and 2c) exhibited nearly uniform pore diameters of 22-42 nm. The thickness of this layer was $242 \pm 33 \mathrm{~nm}$ (Figure 1f). The same formation mechanism can 
be hypothesized for nanoporous $\mathrm{Nb}_{2} \mathrm{O}_{5}$ layer formation as has been described for the formation of the nanoporous $\mathrm{Ta}_{2} \mathrm{O}_{5}$ layer. Niobium $(\mathrm{Nb})$ and $\mathrm{Zr}$ are in the same period and adjacent columns in periodic table of the elements. The standard electrode potential of $\mathrm{Nb} \rightarrow \mathrm{Nb}^{5+}$ is $0.644 \mathrm{~V}$, which is less than that of $\mathrm{Zr} \rightarrow \mathrm{Zr}^{4+}, 1.553 \mathrm{~V}$ [43]; $\mathrm{Nb}$ is, therefore, oxidized rapidly. In addition, the standard enthalpy of formation for $\mathrm{Nb}_{2} \mathrm{O}_{5}$ is -458.640 gram calories per mole, whereas the enthalpy of formation is -264.199 gram calories per mole for $\mathrm{ZrO}_{2}$ [44].

The processes of oxidization and formation of the oxide layer on the niobium surface are more rapid than those on the zirconium surface. Consider, for example, that the physical and chemical environment around the $\left[\mathrm{NbF}_{7}\right]^{2-}$ ion within the pore structure are ignored. The volume of the ion complexes can then be calculated on the basis of the ionic radii for $\mathrm{Nb}^{5+}$ and $\mathrm{F}^{-}$ions and assuming a lattice structure of a two pentagonal pyramid. The volume of the circumscribed sphere of the $\left[\mathrm{NbF}_{7}\right]^{2-}$ ion is calculated as $32.02 \times 10^{-30} \mathrm{~m}^{3}$, which is smaller than the volume of the $\left[\mathrm{ZrF}_{6}\right]^{2-}$ ion, which is $36.08 \times 10^{-30} \mathrm{~m}^{3}$, which is octahedral. It can be expected, therefore, that the diffusion of a $\left[\mathrm{NbF}_{7}\right]^{2-}$ ion within a pore is more rapid than for $\mathrm{a}\left[\mathrm{ZrF}_{6}\right]^{2-}$ ion. The growth of the pore does not arise only at the bottom but also at the walls, which will result in merging of pores.

Figures $1 \mathrm{~g}-\mathrm{i}$ and $2 \mathrm{~d}-\mathrm{f}$ show the fabricated $\mathrm{ZrO}_{2}$ nanotubes that exhibit: (i) uniform inner pore diameters of 21-35 nm; (ii) an outer diameter of 54-68 nm; and (iii) wall thickness of 10-16 nm. The thickness of this layer was about $24.52 \pm 0.74 \mu \mathrm{m}$. As previously explained [45], the standard electrode potential of $\mathrm{Zr} \rightarrow \mathrm{Zr}^{4+}, 1.553 \mathrm{~V}$, is lower than that of $\mathrm{Ti} \rightarrow \mathrm{Ti}^{4+}, 2.132 \mathrm{~V}$ [43], which results in rapid oxidation. In addition, the standard enthalpy of formation for $\mathrm{ZrO}_{2}$ is -264.199 gram calories per mole, whereas that for $\mathrm{TiO}_{2}$ is -228.360 gram calories per mole [44]. The process of oxidation and the formation of the oxide layer on the surface of zirconium are faster than those for the titanium surface. However, the formation of the $\left[\mathrm{ZrF}_{6}\right]^{2-}$ ion takes more time than for the $\left[\mathrm{TiF}_{6}\right]^{2-}$ ion because the solubility equilibrium constant of $\left(\mathrm{NH}_{4}\right)_{2} \mathrm{ZrF}_{6}$ is higher than that of $\left(\mathrm{NH}_{4}\right)_{2} \mathrm{TiF}_{6}$. Based on the hypothesis described previously, the volume of the circumscribed sphere of the octahedral structure of $\left[\mathrm{ZrF}_{6}\right]^{2-}$ can be calculated as $36.08 \times 10^{-30} \mathrm{~m}^{3}$ and $29.18 \times 10^{-30} \mathrm{~m}^{3}$ for $\left[\mathrm{TiF}_{6}\right]^{2-}$, which causes a lower diffusion rate inside the pore. It has been reported that nanotubes grow longer with a smaller diameter when the dissolution rate is slow compared to the oxidation process [46].

\subsection{Physical Characteristics of Nanoporous $\mathrm{Ta}_{2} \mathrm{O}_{5}$ and $\mathrm{Nb}_{2} \mathrm{O}_{5}$ and Nanotubular $\mathrm{ZrO}_{2}$ Layers}

Figure $3 \mathrm{a}$ demonstrates the influence of the formation of nanoporous $\mathrm{Ta}_{2} \mathrm{O}_{5}$ and the $\mathrm{TiO}_{2}$ nanotubes on the $S_{\mathrm{a}}$ with respect to the bare metals. The nanoporous layer of $\mathrm{Ta}_{2} \mathrm{O}_{5}$ revealed a lower surface roughness than the $\mathrm{TiO}_{2}$ nanotubes, with almost the same distribution of inner diameter $\left(D_{i}\right)$, when the concentration of fluoride ion $\left(C_{\mathrm{F}}^{-}\right)$was $0.5 \mathrm{wt} \%$ at $20 \mathrm{~V}$. The roughness similarity arose because the $\mathrm{TiO}_{2}$ nanotubes were separated from each other, whereas the nanoporous $\mathrm{Ta}_{2} \mathrm{O}_{5}$ formed a continuous layer. The surface area index $\left(S_{\mathrm{I}}\right)$ may be calculated by dividing the projected surface area, namely, the total exposed three-dimensional surface area being analyzed, including peaks and valleys, to the surface area measured in the lateral direction. The volume index $\left(V_{\mathrm{I}}\right)$ may be calculated by dividing the natural volume, namely, the amount of liquid that it would take to submerge the dataset to its highest point, to the normal volume that is measured in the lateral of the nanoporous layer. The $S_{\text {I }}$ and $V_{\text {I }}$ values of nanoporous $\mathrm{Ta}_{2} \mathrm{O}_{5}$ are shown in Table 1 , with the corresponding roughness amplitude parameters, and 
verify that the $\mathrm{Ta}_{2} \mathrm{O}_{5}$ nanoporous layer did not significantly change the surface area and roughness of the bare metal. Although the distribution of nanoporous $\mathrm{Ta}_{2} \mathrm{O}_{5}$ was not uniform, there were no high peaks and low valleys according to the measured $S_{\text {skw, }}$, which is close to zero. The peaks and valleys exhibited a platykurtic distribution that was almost uniform due to the $S_{\mathrm{ku}}$ being near to 3 .

Figure $3 \mathrm{~b}$ shows the change of hydrophilic properties of bare tantalum and titanium after fabrication of the nanoporous and nanotubular layers on their surfaces. The water contact angle measurement of a surface represents the wetting properties of the surface. The literature defines a surface as superhydrophobic when the water contact angle $\left(\theta_{\mathrm{w}}\right)$ is more than $150^{\circ}$ and hydrophobic when it is $90^{\circ}<\theta_{\mathrm{w}}<150^{\circ}$. A surface has superhydrophilic properties when $\theta_{\mathrm{w}}<10^{\circ}$ and has hydrophilic properties with a water contact angle $10^{\circ}<\theta_{\mathrm{w}}<90^{\circ}$ [47]. The as-formed nanoporous $\mathrm{Ta}_{2} \mathrm{O}_{5}$ exhibited hydrophilic properties that were similar to the $\mathrm{TiO}_{2}$ nanotubes with the same distribution of inner diameters, $D_{i}$ (under the conditions of $C_{\mathrm{F}}^{-}=0.5 \mathrm{wt} \%, 20 \mathrm{~V}$ ). Figure 4 presents photo images of a water droplet on the surface of nanoporous and nanotubular layers. Figure $3 \mathrm{a}, \mathrm{b}$ also suggests a direct relationship between roughness and water contact angle. When the roughness increased there was a decrease in the water contact angle. The calculated surface energy for nanoporous $\mathrm{Ta}_{2} \mathrm{O}_{5}$ increased after anodization and also after annealing due to the completion of its crystallization. The water contact angle and surface energy have been detailed in Table 2 for nanoporous $\mathrm{Ta}_{2} \mathrm{O}_{5}$.

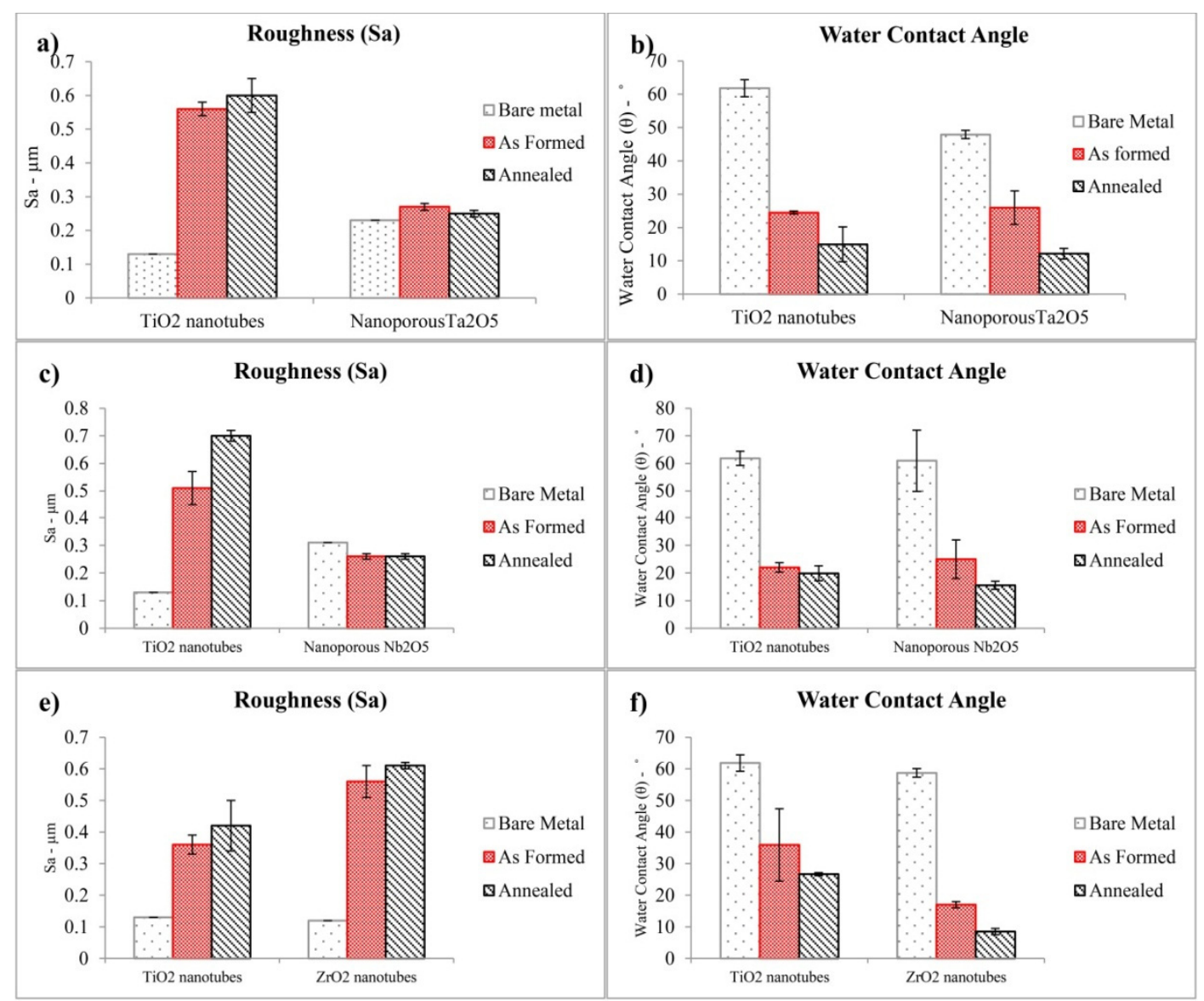

Figure 3. Demonstration of (a,c,e) changes of roughness $\left(S_{\mathrm{a}}\right)$ and $(\mathbf{b}, \mathbf{d}, \mathbf{f})$ modification of water contact angle of bare tantalum, niobium, zirconium and titanium after fabrication of nanotubular and nanoporous layer. Each data point is an average of three measurements. 
Table 1. Surface area and volume index and roughness amplitude parameters of nanoporous $\mathrm{Ta}_{2} \mathrm{O}_{5}, \mathrm{Nb}_{2} \mathrm{O}_{5}$ and nanotube $\mathrm{ZrO}_{2}$. Each data point is an average of three measurements.

\begin{tabular}{|c|c|c|c|c|c|c|}
\hline Material & $\begin{array}{c}\text { Surface area } \\
\text { index }\left(S_{\mathrm{I}}\right)\end{array}$ & $\begin{array}{c}\text { Volume } \\
\text { index }\left(V_{I}\right)\end{array}$ & $S_{\mathrm{a}}(\mu \mathrm{m})$ & $S_{\mathrm{q}}(\mu \mathrm{m})$ & $S_{\text {skw }}$ & $S_{\mathrm{ku}}$ \\
\hline $\begin{array}{l}\text { Nanoporous } \mathrm{Ta}_{2} \mathrm{O}_{5} \\
\text { As formed }\end{array}$ & $1.34 \pm 0.01$ & $18393 \pm 86$ & $0.27 \pm 0.01$ & $0.35 \pm 0.01$ & $0.60 \pm 0.23$ & $4.82 \pm 0.52$ \\
\hline $\begin{array}{c}\text { Nanoporous } \mathrm{Ta}_{2} \mathrm{O}_{5} \\
\text { Annealed }\left(10 \mathrm{~min} \text { at } 290{ }^{\circ} \mathrm{C}\right)\end{array}$ & $1.27 \pm 0.01$ & $1838 \pm 132$ & $0.25 \pm 0.01$ & $0.32 \pm 0.01$ & $0.72 \pm 0.03$ & $3.90 \pm 0.17$ \\
\hline Bare tantalum foil $(0.1 \mathrm{~mm})$ & $1.06 \pm 0.00$ & $18229 \pm 0$ & $0.23 \pm 0.00$ & $0.29 \pm 0.00$ & $0.06 \pm 0.00$ & $2.79 \pm 0.00$ \\
\hline $\begin{array}{l}\text { Nanoporous } \mathrm{Nb}_{2} \mathrm{O}_{5} \\
\text { As formed }\end{array}$ & $1.50 \pm 0.00$ & $18398 \pm 134$ & $0.26 \pm 0.00$ & $0.34 \pm 0.00$ & $0.64 \pm 0.03$ & $3.78 \pm 0.21$ \\
\hline $\begin{array}{c}\text { Nanoporous } \mathrm{Nb}_{2} \mathrm{O}_{5} \\
\text { Annealed }\left(10 \text { min at } 290^{\circ} \mathrm{C}\right)\end{array}$ & $1.38 \pm 0.00$ & $18357 \pm 144$ & $0.26 \pm 0.01$ & $0.33 \pm 0.01$ & $0.39 \pm 0.02$ & $3.28 \pm 0.05$ \\
\hline Bare niobium foil $(0.05 \mathrm{~mm})$ & $1.04 \pm 0.00$ & $18327 \pm 0$ & $0.31 \pm 0.00$ & $0.38 \pm 0.00$ & $0.22 \pm 0.00$ & $2.68 \pm 0.00$ \\
\hline $\begin{array}{l}\mathrm{ZrO}_{2} \text { Nanotube; } \\
\text { As formed }\end{array}$ & $2.44 \pm 0.30$ & $18422 \pm 12$ & $0.56 \pm 0.05$ & $0.71 \pm 0.05$ & $-0.86 \pm 0.018$ & $3.75 \pm 0.49$ \\
\hline $\begin{array}{l}\mathrm{ZrO}_{2} \text { Nanotube; Annealed } \\
\quad\left(10 \text { min at } 290^{\circ} \mathrm{C}\right)\end{array}$ & $2.94 \pm 0.15$ & $18428 \pm 79$ & $0.61 \pm 0.01$ & $0.76 \pm 0.00$ & $-0.57 \pm 0.20$ & $3.30 \pm 0.35$ \\
\hline Bare zirconium foil $(0.05 \mathrm{~mm})$ & $1.03 \pm 0.00$ & $18531 \pm 0.00$ & $0.12 \pm 0.00$ & $0.20 \pm 0.00$ & $-4.27 \pm 0.00$ & $39.31 \pm 0.00$ \\
\hline
\end{tabular}

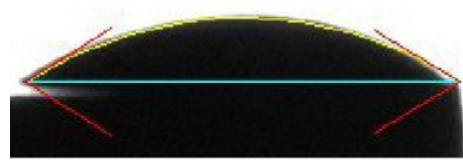

$\mathrm{Ta} 2 \mathrm{O}$-As Formed

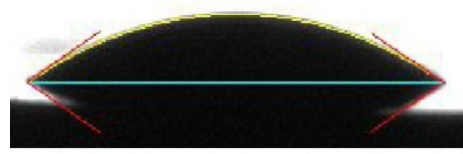

$\mathrm{Nb}_{2} \mathrm{O} 5$-As Formed

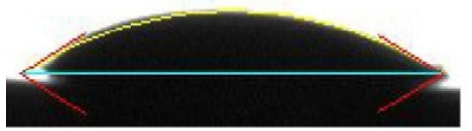

$\mathrm{ZrO} 2-$ As Formed

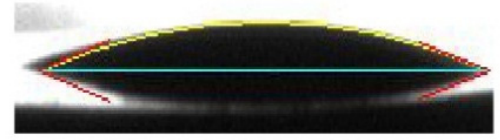

$\mathrm{Ta} 2 \mathrm{O} 5$-Annealed

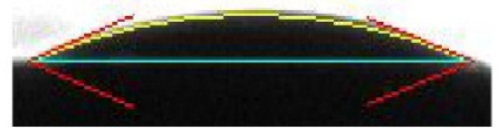

$\mathrm{Nb}_{2} \mathrm{O} 5$-Annealed

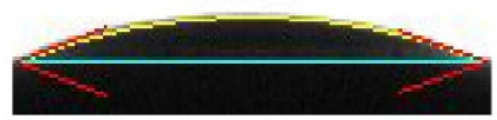

$\mathrm{ZrO} 2$-Annealed

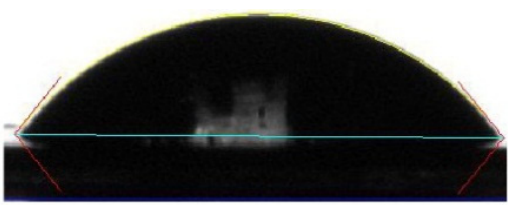

Bare tantalum foil

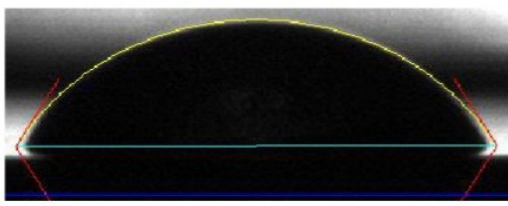

Bare niobium foil

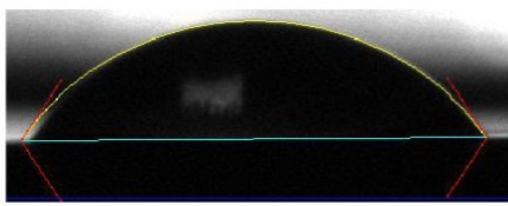

Bare zirconium foil

Figure 4. Photo images of water droplet on the surface of nanoporous and nanotubular layers.

Figure $3 \mathrm{c}$ indicates the progression in roughness for the nanoporous $\mathrm{Nb}_{2} \mathrm{O}_{5}$ layer and $\mathrm{TiO}_{2}$ nanotubes while exhibiting almost the same distribution of $D_{i}$ (under the conditions of $C_{\mathrm{F}}^{-}=0.5 \mathrm{wt} \%, 15 \mathrm{~V}$ ) with respect to the corresponding bare metals. The roughness of the titanium increased upon the creation and separation of $\mathrm{TiO}_{2}$ nanotubes that give rise to gaps in the surface architecture, whereas the roughness of the niobium decreased upon the growth of nanoporous $\mathrm{Nb}_{2} \mathrm{O}_{5}$. The $S_{\text {skw }}$ of the $\mathrm{Nb}_{2} \mathrm{O}_{5}$ nanoporous surface 
is higher than zero, indicating the presence of high peaks and low valleys with a leptokurtic distribution. The surface area and volume indices of nanoporous $\mathrm{Nb}_{2} \mathrm{O}_{5}$ are shown in Table 1, as well as the corresponding roughness amplitude parameters. Figure $3 \mathrm{~d}$ shows the changes of hydrophilic properties of the bare niobium and titanium after fabrication of the nanoporous and nanotubular layers on their surfaces. The nanoporous surface revealed a water contact angle in the range of almost the same distribution of $D_{i}$ (under the conditions of $C_{\mathrm{F}}^{-}=0.5 \mathrm{wt} \%, 15 \mathrm{~V}$ ) for $\mathrm{TiO}_{2}$ nanotubes that showed hydrophilic properties. This data also implies that there is a relationship between roughness and the water contact angle. The surface energy of this layer was higher than bare niobium. The water contact angle and surface energy are listed in Table 2 for the nanoporous $\mathrm{Nb}_{2} \mathrm{O}_{5}$.

Table 2. Water contact angle and surface energy of as formed and annealed nanoporous $\mathrm{Ta}_{2} \mathrm{O}_{5}, \mathrm{Nb}_{2} \mathrm{O}_{5}$ and nanotube $\mathrm{ZrO}_{2}$ in comparison to its bare metal. Each data point is an average of three measurements.

\begin{tabular}{|c|c|c|c|c|}
\hline Material & Contact angle $\left(\theta /{ }^{\circ}\right)$ & $\begin{array}{c}\gamma_{S}^{d} \\
\left(\mathbf{m} \mathbf{J} \cdot \mathbf{m}^{-\mathbf{2}}\right)\end{array}$ & $\begin{array}{c}\boldsymbol{\gamma}_{S}^{p} \\
\left(\mathbf{m J} \cdot \mathbf{m}^{-\mathbf{2}}\right)\end{array}$ & $\begin{array}{c}\gamma_{S}=\gamma_{S}^{d}+\gamma_{S}^{p} \\
\left(\mathbf{m J} \cdot \mathbf{m}^{-\mathbf{2}}\right)\end{array}$ \\
\hline Nanoporous $\mathrm{Ta}_{2} \mathrm{O}_{5}$; As formed & $26.0 \pm 5.0$ & 11.8 & 55.2 & 67.0 \\
\hline Nanoporous $\mathrm{Ta}_{2} \mathrm{O}_{5}$; Annealed $\left(10 \mathrm{~min}\right.$ at $\left.290{ }^{\circ} \mathrm{C}\right)$ & $12.1 \pm 1.6$ & 15.2 & 56.7 & 71.9 \\
\hline Bare tantalum foil $(0.1 \mathrm{~mm})$ & $47.9 \pm 1.2$ & 5.1 & 49.5 & 54.6 \\
\hline Nanoporous $\mathrm{Nb}_{2} \mathrm{O}_{5}$; As formed & $25.0 \pm 7.0$ & 11.02 & 56.94 & 67.96 \\
\hline Nanoporous $\mathrm{Nb}_{2} \mathrm{O}_{5}$; Annealed $\left(10 \mathrm{~min}\right.$ at $\left.290^{\circ} \mathrm{C}\right)$ & $15.5 \pm 1.4$ & 18.11 & 52.20 & 70.31 \\
\hline Bare niobium foil $(0.05 \mathrm{~mm})$ & $61.0 \pm 0.0$ & 6.44 & 34.94 & 41.38 \\
\hline $\mathrm{ZrO}_{2}$ Nanotube; As formed & $17.0 \pm 1.0$ & 11.56 & 60.04 & 71.60 \\
\hline $\mathrm{ZrO}_{2}$ Nanotube; Annealed $\left(10 \mathrm{~min}\right.$ at $\left.290^{\circ} \mathrm{C}\right)$ & $8.5 \pm 1.0$ & 12.84 & 60.77 & 73.61 \\
\hline Bare zirconium foil $(0.05 \mathrm{~mm})$ & $58.7 \pm 1.3$ & 5.82 & 38.042 & 43.87 \\
\hline
\end{tabular}

Figure 3e shows the effect of $\mathrm{ZrO}_{2}$ and $\mathrm{TiO}_{2}$ nanotube formation with respect to the roughness, $S_{\mathrm{a}}$, of the bare metals. The presence of the nanotubular $\mathrm{ZrO}_{2}$ has increased the roughness of the bare metal and also revealed a higher roughness than the nanotubular layer on the $\mathrm{TiO}_{2}$ nanotubes surface with almost the same distribution of $D_{i}$ (under the conditions of $C_{\mathrm{F}}^{-}=0.5 \mathrm{wt} \%, 10 \mathrm{~V}$ ). The $S_{\mathrm{skw}}$ of the $\mathrm{ZrO}_{2}$ nanotubular layer is lower than zero, which signifies deep valleys, such as scratches, with a leptokurtic distribution. The surface area and volume indices of $\mathrm{ZrO}_{2}$ nanotube are shown in Table 1, along with their roughness amplitude parameters.

Modification of the hydrophilic properties of bare zirconium and titanium after fabrication of nanotubular layer on their surfaces is shown in Figure 3f. Although both nanotubular layers fabricated on the zirconium and titanium surfaces are hydrophilic, the $\mathrm{ZrO}_{2}$ nanotubes exhibited a lower water contact angle in comparison to $\mathrm{TiO}_{2}$ with nearly the same distribution of $D_{i}\left(C_{\mathrm{F}}^{-}=0.5 \mathrm{wt} \%, 10 \mathrm{~V}\right)$, which led to a high surface energy. The water contact angle and surface energy is detailed in Table 2 for $\mathrm{ZrO}_{2}$ nanotubes. A direct relationship between roughness and the water contact angle can be observed in Figure 3f.

Nanoporous $\mathrm{Ta}_{2} \mathrm{O}_{5}$ with a mixture of amorphous and hexagonal phase was fabricated via anodization under the conditions of $1 \mathrm{M} \mathrm{H}_{2} \mathrm{SO}_{4}+3.3 \mathrm{wt} \% \mathrm{NH} 4 \mathrm{~F}, 20 \mathrm{~V}$ for $120 \mathrm{~min}$. The amorphous nanoporous $\mathrm{Ta}_{2} \mathrm{O}_{5}$ transformed into hexagonal $\mathrm{Ta}_{2} \mathrm{O}_{5}$ after annealing at $290^{\circ} \mathrm{C}$ for $10 \mathrm{~min}$, as indicated by the XRD patterns in Figure 5a. After annealing the pore size decreased to within the range of $23-49 \mathrm{~nm}$ as a result 
of completion of crystallization. Annealing increased the hydrophilic properties of nanoporous $\mathrm{Ta}_{2} \mathrm{O}_{5}$ layer but as much as $\mathrm{TiO}_{2}$ nanotubes because of their different porosity due to their structures.
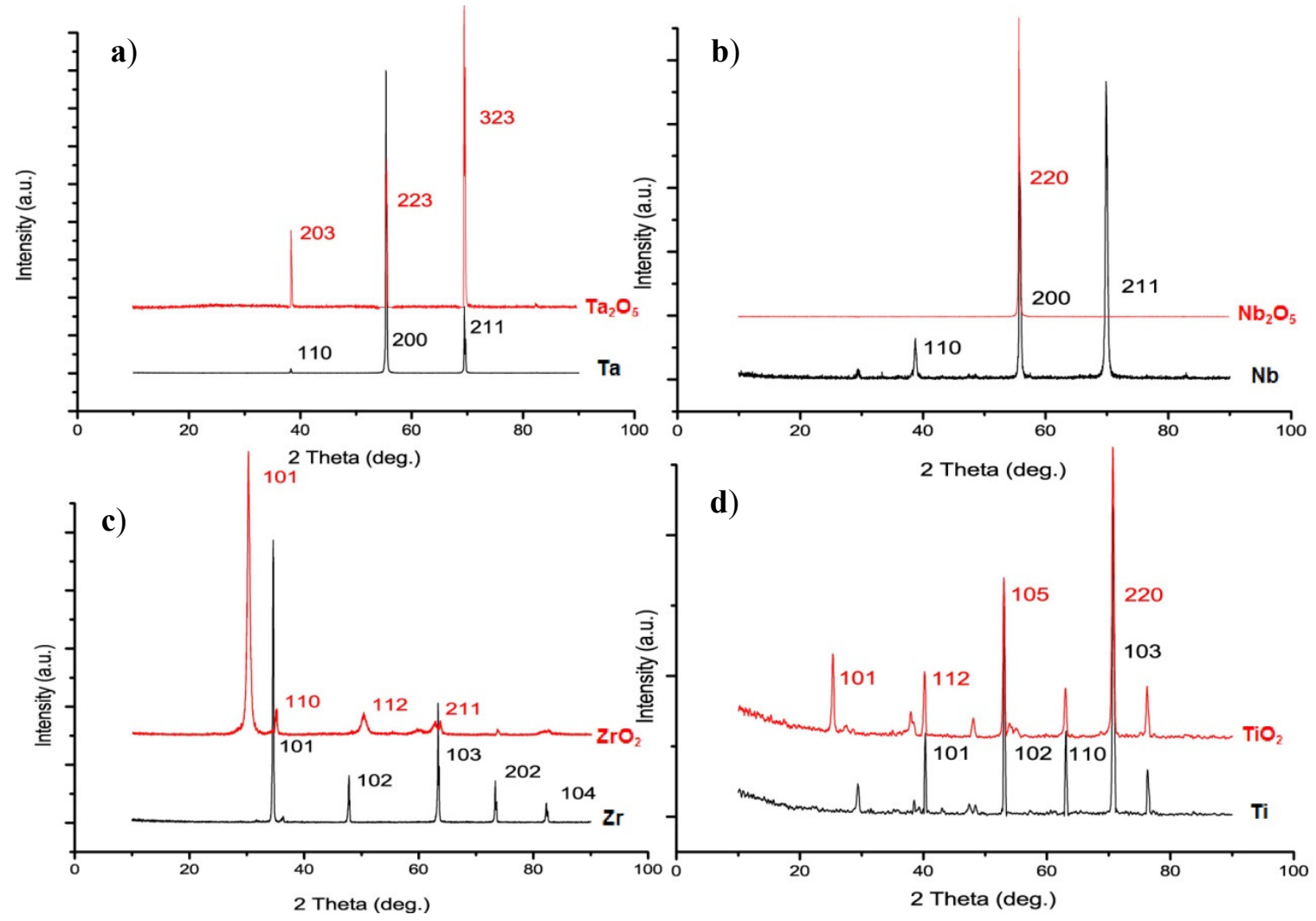

d)

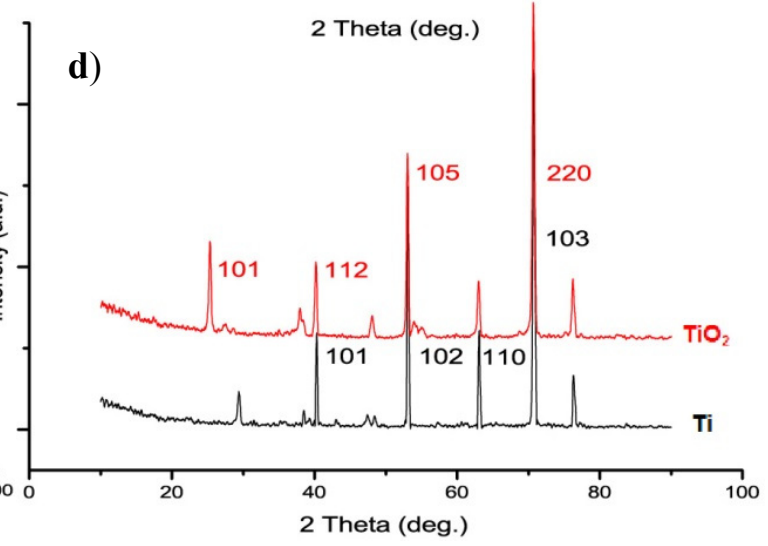

Figure 5. $\mathrm{XRD}$ patterns of (a) the nanoporous $\mathrm{Ta}_{2} \mathrm{O}_{5}$ and bare tantalum foil; (b) the nanoporous $\mathrm{Nb}_{2} \mathrm{O}_{5}$ and bare niobium foil; (c) the $\mathrm{ZrO}_{2}$ nanotubes and bare zirconium foil; and (d) the $\mathrm{TiO}_{2}$ nanotubes and bare titanium foil.

Nanoporous $\mathrm{Nb}_{2} \mathrm{O}_{5}$ with a mixture of amorphous and monoclinic phase was fabricated via anodization under the conditions of $1 \mathrm{M} \mathrm{H}_{2} \mathrm{SO}_{4}+3.3 \mathrm{wt} \% \mathrm{NH}_{4} \mathrm{~F}, 20 \mathrm{~V}$ for $16 \mathrm{~min}$. The amorphous nanoporous $\mathrm{Nb}_{2} \mathrm{O}_{5}$ transformed into base-centered monoclinic $\mathrm{Nb}_{2} \mathrm{O}_{5}$ after annealing at $290{ }^{\circ} \mathrm{C}$ for $10 \mathrm{~min}$, as indicated by the XRD patterns in Figure $5 \mathrm{~b}$. The pore size, after annealing, was irregular and laid in the range of $26-60 \mathrm{~nm}$. The pore size was determined by the crystallization process during the heat treatment. Annealing did not influence the roughness of the nanoporous $\mathrm{Nb}_{2} \mathrm{O}_{5}$ but decreased the water contact angle of the layer.

The cubic $\mathrm{ZrO}_{2}$ nanotube was fabricated via anodization under the conditions of $1 \mathrm{M}\left(\mathrm{NH}_{4}\right)_{2} \mathrm{SO}_{4}+$ $0.3 \mathrm{wt} \% \mathrm{NH}_{4} \mathrm{~F}$ (with the addition of $\mathrm{H}_{2} \mathrm{SO}_{4}$ to attain a $\mathrm{pH}=5$ ) at $30 \mathrm{~V}$ for $95 \mathrm{~min}$, as indicated by the XRD patterns in Figure 5c. After annealing, the inner diameter of the nanotubes laid in the range of 20-36 nm, whilst the nanotube outer diameter $\left(D_{\mathrm{o}}\right)$ was $48-68 \mathrm{~nm}$ and the wall thickness $\left(W_{\mathrm{t}}\right)$ was in the range of 9-11 nm. The roughness $\left(S_{\mathrm{a}}\right)$ and hydrophilic properties of $\mathrm{ZrO}_{2}$ nanotubes increased after annealing. Figure $6 \mathrm{a}$ shows the pore sizes of nanoporous $\mathrm{Ta}_{2} \mathrm{O}_{5}$ and $\mathrm{Nb}_{2} \mathrm{O}_{5}$, compared to $\mathrm{TiO}_{2}$ nanotube with nearly the same $D_{\mathrm{i}}$. Figure $6 \mathrm{~b}, \mathrm{c}$,d shows the $D_{\mathrm{i}}, D_{\mathrm{o}}$ and $W_{\mathrm{t}}$ of $\mathrm{ZrO}_{2}$ nanotubes compared to $\mathrm{TiO}_{2}$ nanotube with nearly the same pore sizes as a visual illustration. 


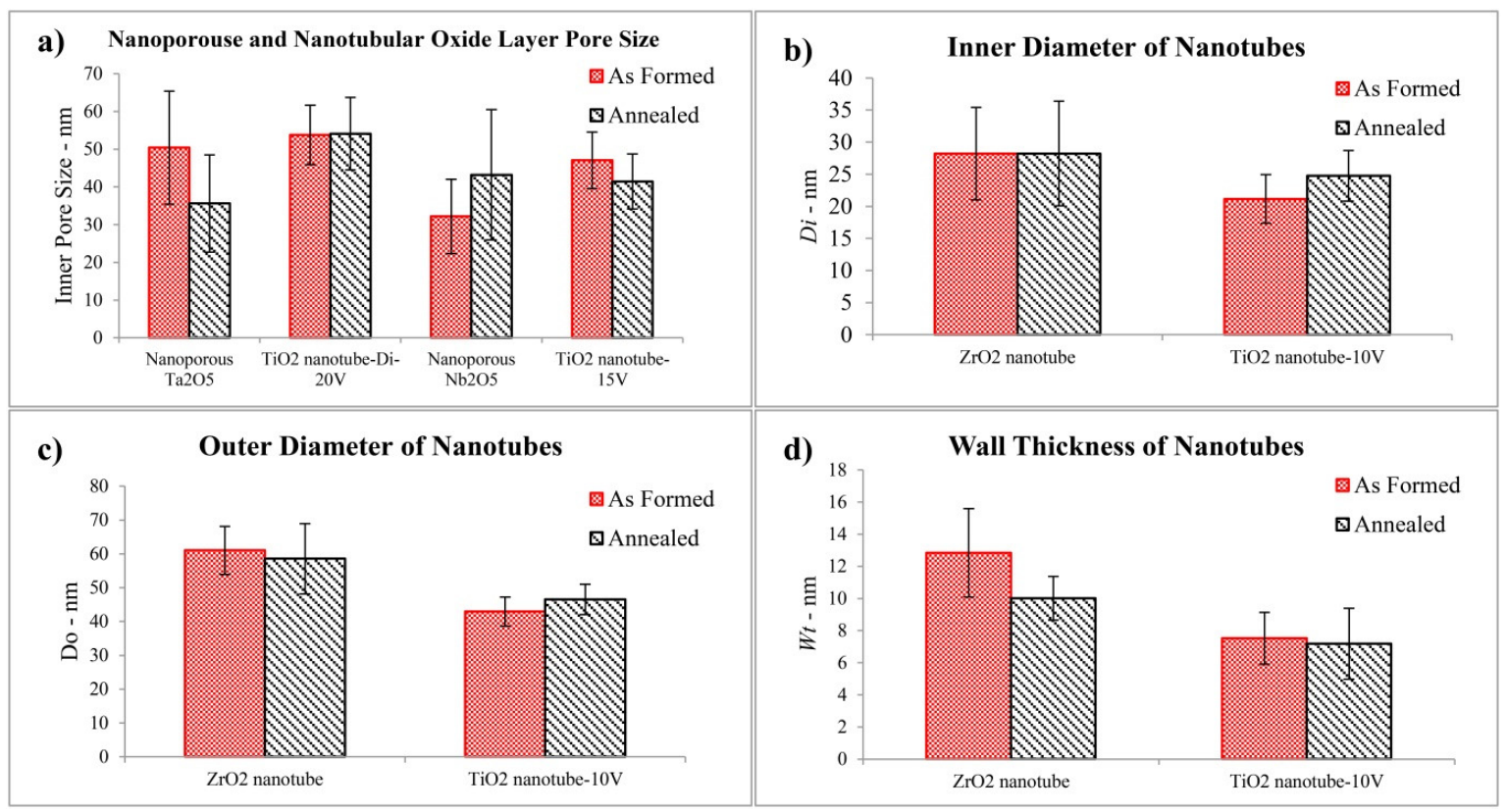

Figure 6. Illustration of pore size of the nanoporous and nanotubular layer.

\subsection{Bioactivity of Nanoporous and Nanotubular Metal Oxide Layer}

Artificial implant materials upon implantation in vivo are encapsulated by fibrous tissues that isolate them from the surrounding bone. This is not the ideal healing mechanism, whereas a bioactive material is preferred which bonds to living bone by forming a carbonated apatite layer on their surfaces similar to hydroxyapatite (HA) of bone composition [48]. The bioactivity of the biocompatible metals with the as-formed and annealed conditions of the nanoporous and nanotubular metal oxides was assessed by immersion in the m-SBF for a period up to three weeks. The response of the oxide layers to the $\mathrm{m}-\mathrm{SBF}$ immersion was observed after one day and three weeks. After one-day immersion, no growth of HA was detectable on the surfaces of the as-formed and annealed nanoporous $\mathrm{Ta}_{2} \mathrm{O}_{5}$ and $\mathrm{Nb}_{2} \mathrm{O}_{5}$ and the nanotubular $\mathrm{TiO}_{2}$ and $\mathrm{ZrO}_{2}$. However, after three weeks immersion as shown in Figure 7, HA were deposited onto the surfaces of the nanoporous and nanotubular layers. The atomic ratio of calcium to phosphate calculated using EDS results after three weeks is indicated in Figure 8.

The $\mathrm{M}-\mathrm{OH}$ groups located on the surface of biocompatible metal oxides are favored sites for apatite nucleation [48-51]. First, $\mathrm{Ca}^{2+}$ ions are absorbed onto the hydrolyzed nanoporous and nanotubular oxide surface by Coulomb attraction forces. Then, existing phosphate groups inside the m-SBF are adsorbed to the positively charged surface, resulting in the formation of calcium phosphate. The stoichiometric $\mathrm{Ca} / \mathrm{P}\left(\right.$ at.\%) of octacalcium phosphate $\left[\mathrm{Ca}_{8} \mathrm{H}_{2}\left(\mathrm{PO}_{4}\right)_{6} \times 5 \mathrm{H}_{2} \mathrm{O}\right]$, tricalcium phosphate $\left[\mathrm{Ca}_{3}\left(\mathrm{PO}_{4}\right)_{2}\right]$ and hydroxyapatite $\left[\mathrm{Ca}_{10}\left(\mathrm{PO}_{4}\right)_{6}(\mathrm{OH})_{2}\right]$ are 1.33, 1.5 and 1.67, respectively. According to the obtained $\mathrm{Ca} / \mathrm{P}$ ratio for the metal oxides, annealed nanoporous $\mathrm{Ta}_{2} \mathrm{O}_{5}$ had a high value of $\mathrm{Ca} / \mathrm{P}$ ratio, which may indicate the presence of a mixture of calcium and phosphate in abovementioned compositions. Other nanoporous and nanotubular metal oxide layers induce calcium phosphate and need more time or pre-treatment to induce crystalline hydroxyapatite. $\mathrm{Ta}_{2} \mathrm{O}_{5}$ reaches an isoelectric point at a $\mathrm{pH}$ of 2.7-3.0, which can be compared to $\mathrm{Nb}_{2} \mathrm{O}_{5}$ that attains an isoelectric point at a $\mathrm{pH}$ of $4.0[52,53]$. Thus, the $\mathrm{Ta}_{2} \mathrm{O}_{5}$ surface, compared to the $\mathrm{Nb}_{2} \mathrm{O}_{5}$ surface, becomes more negatively charged in $\mathrm{m}-\mathrm{SBF}$ at a $\mathrm{pH}$ of 7.4. Therefore there is an appropriate chemical environment for a higher $\mathrm{Ca} / \mathrm{P}$ atomic ratio to be attained for $\mathrm{Ta}_{2} \mathrm{O}_{5}$ in 
comparison to $\mathrm{Nb}_{2} \mathrm{O}_{5}$. After annealing, the hydrophilic properties and surface energy of both nanoporous $\mathrm{Ta}_{2} \mathrm{O}_{5}$ and $\mathrm{Nb}_{2} \mathrm{O}_{5}$ increased along with no considerable change on their roughness. It can be concluded that a direct link exists between the hydrophilic properties and the completing crystalline phase of nanoporous layer for inducing the formation and growth of HA. The lower value of $S_{\mathrm{ku}}$ of the nanoporous $\mathrm{Nb}_{2} \mathrm{O}_{5}$ plus low tendency to form $\mathrm{Nb}-\mathrm{OH}$, because of its isoelectric point, made the as-formed nanoporous layer non-bioactive in this study. In addition, the isoelectric point of $\mathrm{TiO}_{2}$ has been reported at a $\mathrm{pH}$ of 3.9 and the corresponding value for $\mathrm{ZrO}_{2}$ is $5.5[52,53]$, which would be expected to lead to a higher $\mathrm{Ca} / \mathrm{P}$ ratio for $\mathrm{TiO}_{2}$. After annealing, the hydrophilic properties and surface energy of both $\mathrm{ZrO}_{2}$ and $\mathrm{TiO}_{2}$ nanotubes increased along with the roughness. The roughness of the nanotubular layer and capillary force of nanotubes influenced the initial reaction sites for apatite nucleation and formation.
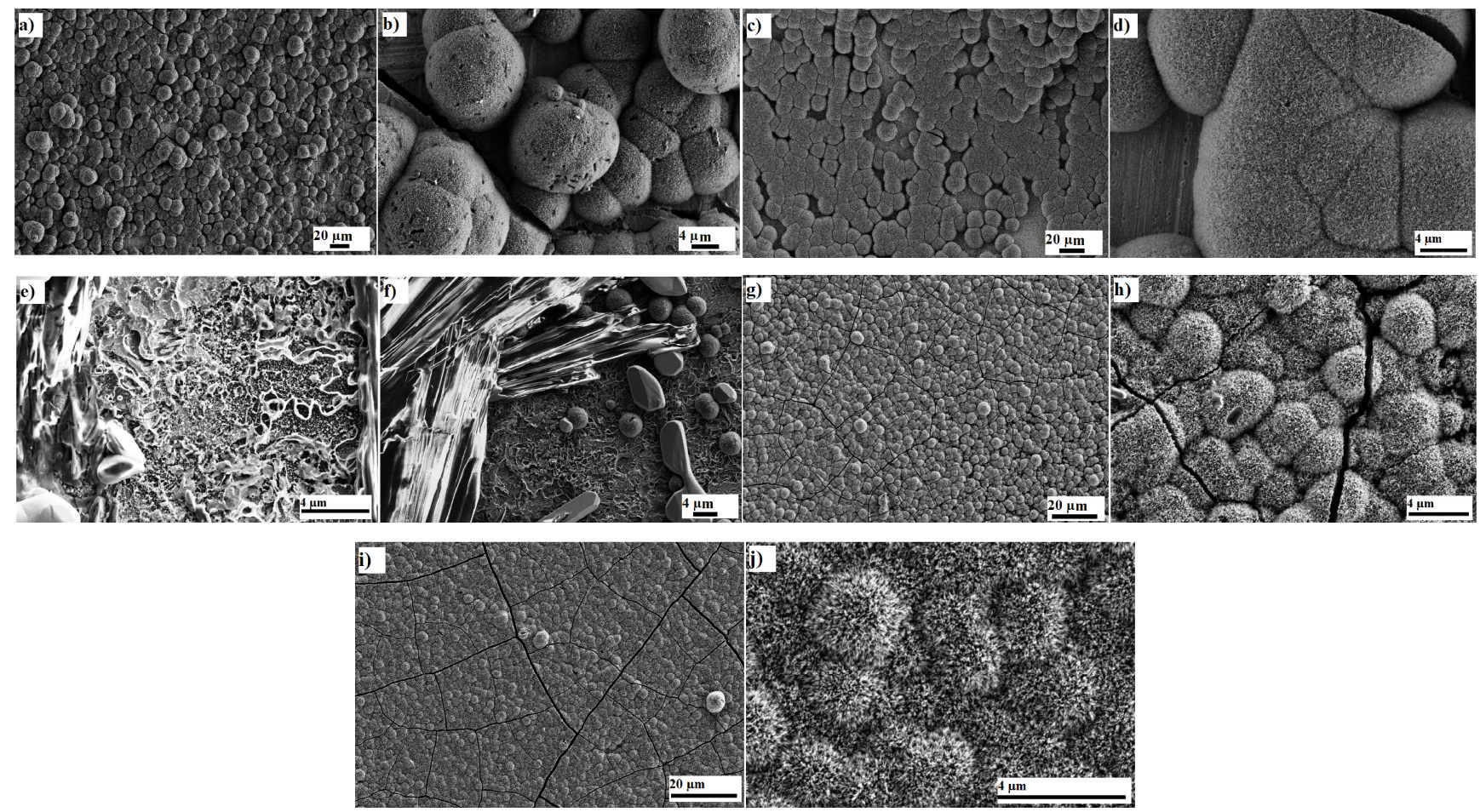

Figure 7. SEM images with $(\mathbf{a}, \mathbf{e}, \mathbf{g})$ low and $(\mathbf{b}, \mathbf{h})$ high magnification of HA on as formed nanoporous $\mathrm{Ta}_{2} \mathrm{O}_{5}, \mathrm{Nb}_{2} \mathrm{O}_{5}$ and $\mathrm{ZrO}_{2}$; and $(\mathbf{c}, \mathbf{i})$ low and $(\mathbf{d}, \mathbf{f}, \mathbf{j})$ high magnification of hydroxyapatite (HA) on annealed nanoporous $\mathrm{Ta}_{2} \mathrm{O}_{5}, \mathrm{Nb}_{2} \mathrm{O}_{5}$ and $\mathrm{ZrO}_{2}$.

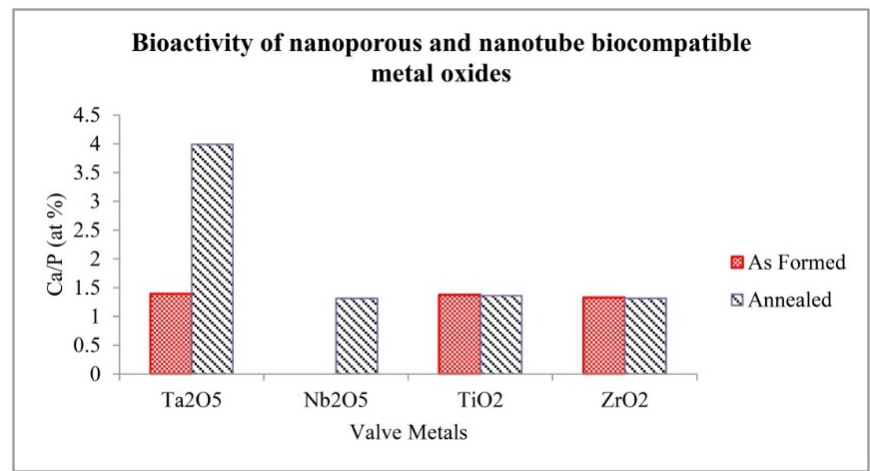

Figure 8. Bioactivity of biocompatible nanoporous and nanotubular oxide metals after 3 weeks in $\mathrm{m}-\mathrm{SBF}$ at $37^{\circ} \mathrm{C}$. 


\section{Experimental Section}

\subsection{Substrate Preparation}

Tantalum, 99.95\% $(10 \mathrm{~mm} \times 10 \mathrm{~mm} \times 0.1 \mathrm{~mm})$, niobium, $99.95 \%(10 \mathrm{~mm} \times 10 \mathrm{~mm} \times 0.05 \mathrm{~mm})$, zirconium, $99.60 \%(10 \mathrm{~mm} \times 10 \mathrm{~mm} \times 0.05 \mathrm{~mm})$ and titanium, $99.95 \%(10 \mathrm{~mm} \times 10 \mathrm{~mm} \times 0.05 \mathrm{~mm})$ foils (Baoji Boxin Metal Materials Co. Ltd., Shaanxi, China) were degreased by sonication in methanol, isopropanol, acetone and ethanol for 15 min each, progressively. The substrates were then washed with deionized water and dried using a nitrogen gas stream. Two electrode configurations were employed using a DC power supply with a $1 \mathrm{~cm}^{2}$ platinum plate acting as the counter electrode and placed $4 \mathrm{~cm}$ from the working electrode. Electrochemical experiments were performed at room temperature with the electrolyte composed of $1 \mathrm{M} \mathrm{H}_{2} \mathrm{SO}_{4}+3.3 \mathrm{wt} \% \mathrm{NH}_{4} \mathrm{~F}$ for tantalum and niobium at $20 \mathrm{~V}$ for $120 \mathrm{~min}$ and 16 min, respectively; $1 \mathrm{M}\left(\mathrm{NH}_{4}\right)_{2} \mathrm{SO}_{4}+0.3 \mathrm{wt} \% \mathrm{NH}_{4} \mathrm{~F}$ (with the addition of $\mathrm{H}_{2} \mathrm{SO}_{4}$ to attain $\mathrm{pH}$ 5) for zirconium at $30 \mathrm{~V}$ for $95 \mathrm{~min}$ and $1 \mathrm{M} \mathrm{H}_{2} \mathrm{SO}_{4}+0.5 \mathrm{wt} \% \mathrm{NH}_{4} \mathrm{~F}$ for titanium at 10,15 and $20 \mathrm{~V}$ for $120 \mathrm{~min}$. The electrolytes were prepared from reagent grade chemicals (Sigma Aldridge, Castle Hill, Australia) and deionized water. After the electrochemical treatment, the samples were rinsed with deionized water for $5 \mathrm{~min}$ and dried with a nitrogen stream. Annealing of the samples was performed in air at $290{ }^{\circ} \mathrm{C}$ for $10 \mathrm{~min}$ in a conventional muffle furnace (Nabertherm LT15/13/P330; Nabertherm $\mathrm{GmbH}$, Lilienthal, Germany).

\subsection{Surface Characterization}

Metallographic characterization of the samples was carried out using a field-emission scanning electron microscope (FESEM, ZEISS SUPRA 40 VP, Los Angeles, CA, USA). The characterization of the phase structures was performed by means of XRD using $\mathrm{Cu} \mathrm{K \alpha}$ incident radiation at $40 \mathrm{kV}$ and $40 \mathrm{~mA}$ (Bruker D8; Bruker Pte Ltd., Singapore). The diffraction patterns were recorded over a $2 \theta$ range from $10^{\circ}$ to $90^{\circ}$ scanned at a step size of $0.02^{\circ}$. For the nanoporous $\mathrm{Ta}_{2} \mathrm{O}_{5}$ and $\mathrm{Nb}_{2} \mathrm{O}_{5}$ layers, the films were scratched off and characterized using XRD.

Roughness parameters were measured using a 3D-Profilometer (Bruker, Contour GT-K1; Bruker Pte Ltd., Singapore) and analyzed using the SurfVision software (Veeco Instruments Inc.; Plainview, NY, USA). Surface topography was characterized by four parameters. Mean Roughness $\left(S_{\mathrm{a}}\right)$ and Root Mean Square (RMS) Roughness $\left(S_{\mathrm{q}}\right)$ were used to evaluate the vertical characteristics of surface deviation over the 3D surface [54]. The third central moment of profile amplitude, skewness of a 3D surface texture ( $S_{\text {skw }}$ ) was used to assess the dominant nature of topography. Thus, a value of $S_{\text {skw }}>0$ indicates high peaks about the mean plane and $S_{\text {skw }}<0$ indicates deep valleys such as would be formed from scratches [54]. The sharpness of the height distribution was indicated by a fourth central moment of profile amplitude; that is the kurtosis $\left(S_{\mathrm{ku}}\right)$ of the $3 \mathrm{D}$ surface texture where $S_{\mathrm{ku}}=3.0$ for a normal distribution of heights. However, when a few high peaks are spread out over the 3D surface, then the distribution is defined as "platykurtic" and $S_{\mathrm{ku}}<3.0$; whereas $S_{\mathrm{ku}}>3.0$ in the instance of the surface exhibiting a high proportion of high peaks and low valleys and this distribution is described as being "leptokurtic" [54]. 
The water contact angle was measured using a goniometer (NRL C.A. Goniometer, Ramé-hart, Inc.; Succasunna, NJ, USA). Surface energy is calculated based on Owens-Wendt (OW) method [55], as in the following equation:

$$
(1+\cos \theta) \gamma_{L}=2\left(\sqrt{\gamma_{L}^{d} \gamma_{S}^{d}}+\sqrt{\gamma_{L}^{p} \gamma_{S}^{p}}\right)
$$

where $\gamma_{L}$ is the liquid surface tension (water $=72.8 \mathrm{~mJ} \cdot \mathrm{m}^{-2}$, glycerol $=63.4 \mathrm{~mJ} \cdot \mathrm{m}^{-2}$ ); $\gamma_{L}^{d}$ and $\gamma_{S}^{d}$ are the liquid and solid dispersive component (water $=21.8 \mathrm{~mJ} \cdot \mathrm{m}^{-2}$, glycerol $=37.0 \mathrm{~mJ} \cdot \mathrm{m}^{-2}$ ); $\gamma_{L}^{p}$ and $\gamma_{S}^{p}$ are the liquid and solid polar component (water $=51.0 \mathrm{~mJ} \cdot \mathrm{m}^{-2}$, glycerol $=26.4 \mathrm{~mJ} \cdot \mathrm{m}^{-2}$ ), and $\gamma_{S}$ is the sum of $\gamma_{S}^{d}$ and $\gamma_{S}^{p}[56]$.

Bioactivity assessments were carried out by soaking the as-formed and annealed metal oxides samples in modified simulated body fluid (m-SBF) and incubating them at $37{ }^{\circ} \mathrm{C}$ for 1 day and 3 weeks. A modified simulated body (m-SBF) [57] with an ion composition nearly equal to blood plasma was prepared by dissolving $5.403 \mathrm{~g} \mathrm{NaCl}, 0.504 \mathrm{~g} \mathrm{NaHCO}_{3}, 0.426 \mathrm{~g} \mathrm{Na}_{2} \mathrm{CO}_{3}, 0.225 \mathrm{~g} \mathrm{KCl}, 0.230 \mathrm{~g}$ $\mathrm{K}_{2} \mathrm{HPO}_{4} .3 \mathrm{H}_{2} \mathrm{O}, 0.311 \mathrm{~g} \mathrm{MgCl}_{2} .6 \mathrm{H}_{2} \mathrm{O}, 0.293 \mathrm{~g} \mathrm{CaCl}_{2}$, and $0.072 \mathrm{~g} \mathrm{Na}_{2} \mathrm{SO}_{4}$ in deionized water as previously reported [57]. The m-SBF was buffered at pH 7.4 at $37{ }^{\circ} \mathrm{C}$ using 2-(4-(2-hydroxyethyl)-1piperazinyl) ethane sulfonic acid (aka HEPES) and $1 \mathrm{M} \mathrm{NaOH}$. An amount of $17.892 \mathrm{~g}$ HEPES was dissolved in $100 \mathrm{~mL} 0.2 \mathrm{M} \mathrm{NaOH}$. The ability of the nanostructural surfaces to form apatite was evaluated in a static $\mathrm{m}-\mathrm{SBF}$ environment. The samples were removed after incubation for 1 day and 3 weeks in $\mathrm{m}-\mathrm{SBF}$; then rinsed with deionized water and dried for $24 \mathrm{~h}$ at room temperature. The atomic percentage of calcium to phosphorous $(\mathrm{Ca} / \mathrm{P})$ ratio was calculated using EDS results.

The nano size distribution measurements were generated from 100 nano-pores or nanotubes at different positions for each sample using the line tool of ImageJ software. An average of three readings per sample was acquired for the roughness parameters, water contact and surface energy measurements.

\section{Conclusions}

Nanoporous oxide layers on the surfaces of tantalum and niobium and nanotubular layers on the surfaces of zirconium and titanium were fabricated via anodization. The bioactivity of the nanoporous and nanotubular layers was evaluated. The prime conclusions are as follows.

1. The nanoporous $\mathrm{Ta}_{2} \mathrm{O}_{5}$ layer and nanotubular $\mathrm{ZrO}_{2}$ and $\mathrm{TiO}_{2}$ layer exhibited a higher roughness than their respective bare metals but the nanoporous $\mathrm{Nb}_{2} \mathrm{O}_{5}$ layer exhibited a lower roughness than its bare metal.

2. The nanoporous layers of $\mathrm{Ta}_{2} \mathrm{O}_{5}$ and $\mathrm{Nb}_{2} \mathrm{O}_{5}$ and the nanotubular layers of $\mathrm{ZrO}_{2}$ and $\mathrm{TiO}_{2}$ revealed an increase in hydrophilic property and surface energy compared to their respective bare metals.

3. The hydrophilic property and the surface energy of the nanoporous layers of $\mathrm{Ta}_{2} \mathrm{O}_{5}$ and $\mathrm{Nb}_{2} \mathrm{O}_{5}$ and the nanotubular layers of $\mathrm{ZrO}_{2}$ and $\mathrm{TiO}_{2}$ were increased after annealing.

4. After annealing the pore size of nanoporous $\mathrm{Ta}_{2} \mathrm{O}_{5}$ decreased, whereas the pore size of nanoporous $\mathrm{Nb}_{2} \mathrm{O}_{5}$ increased. This is due to their different crystalline phases before and after annealing which possess different lattice parameters. The inner diameter of $\mathrm{ZrO}_{2}$ nanotubes did 
not show any obvious change after annealing because the crystalline phase did not change, whilst annealing led to an increase in the inner diameter of anatase $\mathrm{TiO}_{2}$ nanotubes.

5. As formed $\mathrm{Ta}_{2} \mathrm{O}_{5}$ and $\mathrm{ZrO}_{2}$ exhibited a good bioactivity similar to $\mathrm{TiO}_{2}$. Annealed $\mathrm{Ta}_{2} \mathrm{O}_{5}$ showed a high level of bioactivity, which is promising for biomedical applications. $\mathrm{Nb}_{2} \mathrm{O}_{5}$ did not show bioactivity before annealing; but was bioactive after annealing.

\section{Acknowledgments}

This research is supported by the Australian Research Council (ARC) through the ARC Discovery Project DP110101974. SM would like to acknowledge the State Government of Victoria in Australia for supporting and funding this research project through a Victorian International Research Scholarship.

\section{Author Contributions}

Sepideh Minagar conceived (90\%) and designed the experiments (95\%), analyzed the data (100\%) and wrote (95\%) and edited the paper (80\%); Cuie Wen conceived (10\%) and designed the experiments $(5 \%)$, wrote $(10 \%)$ and edited the paper (10\%) and Christopher C. Berndt edited the paper $(10 \%)$.

\section{Conflicts of Interest}

The authors declare no conflict of interest.

\section{References}

1. Ishikawa, M.; Sugimoto, K. Multiple layer protective coating composed of $\mathrm{Ta}_{2} \mathrm{O}_{5}, \mathrm{Cr}_{2} \mathrm{O}_{3}$ and $\mathrm{Al}_{2} \mathrm{O}_{3}$ produced by the MO-CVD technique. Corros. Eng. 1989, 38, 619-630.

2. Arnould, C.; Delhalle, J.; Mekhalif, Z. Corrigendum to "Multifunctional hybrid coating on titanium towards hydroxyapatite growth: Electrodeposition of tantalum and its molecular functionalization with organophosphonic acids films" [electrochim. Acta 53 (2008) 5632-5638] (doi:10.1016/j.Electacta. 2008.03.003). Electrochim. Acta 2009, 54, 2402.

3. Arnould, C.; Delhalle, J.; Mekhalif, Z. Multifunctional hybrid coating on titanium towards hydroxyapatite growth: Electrodeposition of tantalum and its molecular functionalization with organophosphonic acids films. Electrochim. Acta 2008, 53, 5632-5638.

4. Arnould, C.; Volcke, C.; Lamarque, C.; Thiry, P.A.; Delhalle, J.; Mekhalif, Z. Titanium modified with layer-by-layer sol-gel tantalum oxide and an organodiphosphonic acid: A coating for hydroxyapatite growth. J. Colloid Interface Sci. 2009, 336, 497-503.

5. Cava, R.F.; Peck, W.F.; Krajewski, J.J. Enhancement of the dielectric-constant of $\mathrm{Ta}_{2} \mathrm{O}_{5}$ through substitution with $\mathrm{TiO}_{2}$. Nature 1995, 377, 215-217.

6. Levine, B.R.; Sporer, S.; Poggie, R.A.; Della Valle, C.J.; Jacobs, J.J. Experimental and clinical performance of porous tantalum in orthopedic surgery. Biomaterials 2006, 27, 4671-4681.

7. Sieber, I.; Kannan, B.; Schmuki, P. Self-assembled porous tantalum oxide prepared in $\mathrm{H}_{2} \mathrm{SO}_{4} / \mathrm{HF}$ electrolytes. Electrochem. Solid-State Lett. 2005, 8, J10-J12.

8. Sieber, I.; Hildebrand, H.; Friedrich, A.; Schmuki, P. Initiation of tantalum oxide pores grown on tantalum by potentiodynamic anodic oxidation. J. Electroceram. 2006, 16, 35-39. 
9. Sieber, I.V.; Schmuki, P. Porous tantalum oxide prepared by electrochemical anodic oxidation. J. Electrochem. Soc. 2005, 152, C639-C644.

10. Wei, W.; MacAk, J.M.; Shrestha, N.K.; Schmuki, P. Thick self-ordered nanoporous $\mathrm{Ta}_{2} \mathrm{O}_{5}$ films with long-range lateral order. J. Electrochem. Soc. 2009, 156, K104-K109.

11. Wei, W.; Macak, J.M.; Schmuki, P. High aspect ratio ordered nanoporous $\mathrm{Ta}_{2} \mathrm{O}_{5}$ films by anodization of Ta. Electrochem. Commun. 2008, 10, 428-432.

12. Aagard, R.L. Optical waveguide characteristics of reactive DC-sputtered niobium pentoxide films. Appl. Phys. Lett. 1975, 27, 605-607.

13. Velten, D.; Eisenbarth, E.; Schanne, N.; Breme, J. Biocompatible $\mathrm{Nb}_{2} \mathrm{O}_{5}$ thin films prepared by means of the sol-gel process. J. Mater. Sci. Mater. Med. 2004, 15, 457-461.

14. Mozalev, A.; Sakairi, M.; Saeki, I.; Takahashi, H. Nucleation and growth of the nanostructured anodic oxides on tantalum and niobium under the porous alumina film. Electrochim. Acta 2003, 48, 3155-3170.

15. Sieber, I.; Hildebrand, H.; Friedrich, A.; Schmuki, P. Formation of self-organized niobium porous oxide on niobium. Electrochem. Commun. 2005, 7, 97-100.

16. Lu, Q.; Hashimoto, T.; Skeldon, P.; Thompson, G.E.; Habazaki, H.; Shimizu, K. Nanoporous anodic niobium oxide formed in phosphate/glycerol electrolyte. Electrochem. Solid-State Lett. 2005, 8, B17-B20.

17. Chambon, L.; Maleysson, C.; Pauly, A.; Germain, J.P.; Demarne, V.; Grisel, A. Investigation, for $\mathrm{NH}_{3}$ gas sensing applications, of the $\mathrm{Nb}_{2} \mathrm{O}_{5}$ semiconducting oxide in the presence of interferent species such as oxygen and humidity. Sens. Actuators B Chem. 1997, 45, 107-114.

18. Tanabe, K.; Okazaki, S. Various reactions catalyzed by niobium compounds and materials. Appl. Catal. A Gen. 1995, 133, 191-218.

19. Pawlicka, A.; Atik, M.; Aegerter, M.A. Synthesis of multicolor $\mathrm{Nb}_{2} \mathrm{O}_{5}$ coatings for electrochromic devices. Thin Solid Films 1997, 301, 236-241.

20. Choi, J.; Lim, J.H.; Lee, S.C.; Chang, J.H.; Kim, K.J.; Cho, M.A. Porous niobium oxide films prepared by anodization in $\mathrm{HF} / \mathrm{H}_{3} \mathrm{PO}_{4}$. Electrochim. Acta 2006, 51, 5502-5507.

21. Choi, J.; Lim, J.H.; Lee, J.; Kim, K.J. Porous niobium oxide films prepared by anodizationannealing-anodization. Nanotechnology 2007, 18, doi:10.1088/0957-4484/18/5/055603.

22. Yamaguchi, T. Application of $\mathrm{ZrO}_{2}$ as a catalyst and a catalyst support. Catal. Today 1994, 20, 199-217.

23. Bethke, K.A.; Kung, M.C.; Yang, B.; Shah, M.; Alt, D.; Li, C.; Kung, H.H. Metal oxide catalysts for lean $\mathrm{NO}_{x}$ reduction. Catal. Today 1995, 26, 169-183.

24. Hahn, R.; Berger, S.; Schmuki, P. Bright visible luminescence of self-organized $\mathrm{ZrO}_{2}$ nanotubes. J. Solid State Electrochem. 2010, 14, 285-288.

25. Tsuchiya, H.; Schmuki, P. Thick self-organized porous zirconium oxide formed in $\mathrm{H}_{2} \mathrm{SO}_{4} / \mathrm{NH}_{4} \mathrm{~F}$ electrolytes. Electrochem. Commun. 2004, 6, 1131-1134.

26. Tsuchiya, H.; Macak, J.M.; Taveira, L.; Schmuki, P. Fabrication and characterization of smooth high aspect ratio zirconia nanotubes. Chem. Phys. Lett. 2005, 410, 188-191.

27. Schmuki, P.; Tsuchiya, H.; Macak, J.; Taveira, L. Formation of self-organized zirconia nanostructure. ECS Trans. 2006, 1, 351-357. 
28. Berger, S.; Faltenbacher, J.; Bauer, S.; Schmuki, P. Enhanced self-ordering of anodic $\mathrm{ZrO}_{2}$ nanotubes in inorganic and organic electrolytes using two-step anodization. Phys. Status Solidi RRL 2008, 2, 102-104.

29. Berger, S.; Jakubka, F.; Schmuki, P. Formation of hexagonally ordered nanoporous anodic zirconia. Electrochem. Commun. 2008, 10, 1916-1919.

30. Shin, Y.; Lee, S. A freestanding membrane of highly ordered anodic $\mathrm{ZrO}_{2}$ nanotube arrays. Nanotechnology 2009, 20, doi:10.1088/0957-4484/20/10/105301.

31. Kokubo, T.; Kim, H.-M.; Kawashita, M. Novel bioactive materials with different mechanical properties. Biomaterials 2003, 24, 2161-2175.

32. Kim, H.-M.; Kaneko, H.; Kokubo, T.; Miyazaki, T.; Nakamura, T. Mechanism of apatite formation on bioactive tantalum metal in simulated body fluid. Key Eng. Mater. 2003, 240-242, 11-14.

33. Nagarajan, S.; Raman, V.; Rajendran, N. Synthesis and electrochemical characterization of porous niobium oxide coated 3161 ss for orthopedic applications. Mater. Chem. Phys. 2010, 119, 363-366.

34. Wang, X.J.; Xiong, J.Y.; Li, Y.C.; Hodgson, P.D.; Wen, C.E. Apatite formation on nano-structured titanium and niobium surface. Mater. Sci. Forum 2009, 614, 85-92.

35. Tang, Z.; Xie, Y.; Yang, F.; Huang, Y.; Wang, C.; Dai, K.; Zheng, X.; Zhang, X. Porous tantalum coatings prepared by vacuum plasma spraying enhance bmscs osteogenic differentiation and bone regeneration in vitro and in vivo. PLoS ONE 2013, 8, e66263.

36. Godley, R.; Starosvetsky, D.; Gotman, I. Bonelike apatite formation on niobium metal treated in aqueous NaOH. J. Mater. Sci. Mater. Med. 2004, 15, 1073-1077.

37. Guo, L.; Zhao, J.; Wang, X.; Xu, R.; Lu, Z.; Li, Y. Bioactivity of zirconia nanotube arrays fabricated by electrochemical anodization. Mater. Sci. Eng. C 2009, 29, 1174-1177.

38. Guo, L.; Zhao, J.; Wang, X.; Xu, X.; Liu, H.; Li, Y. Structure and bioactivity of zirconia nanotube arrays fabricated by anodization. Int. J. Appl. Ceram. Technol. 2009, 6, 636-641.

39. Wang, L.N.; Adams, A.; Luo, J.L. Enhancement of the capability of hydroxyapatite formation on $\mathrm{Zr}$ with anodic $\mathrm{ZrO}_{2}$ nanotubular arrays via an effective dipping pretreatment. J. Biomed. Mater. Res. B Appl. Biomater. 2011, 99, 291-301.

40. Gomez Sanchez, A.; Ballarre, J.; Orellano, J.C.; Duffó, G.; Ceré, S. Surface modification of zirconium by anodisation as material for permanent implants: In vitro and in vivo study. J. Mater. Sci. Mater. Med. 2013, 24, 161-169.

41. Minagar, S.; Berndt, C.C.; Wang, J.; Ivanova, E.; Wen, C. A review of the application of anodization for the fabrication of nanotubes on metal implant surfaces. Acta Biomater. 2012, 8, 2875-2888.

42. Macak, J.M.; Tsuchiya, H.; Ghicov, A.; Yasuda, K.; Hahn, R.; Bauer, S.; Schmuki, P. TiO 2 nanotubes: Self-organized electrochemical formation, properties and applications. Curr. Opin. Solid State Mater. Sci. 2007, 11, 3-18.

43. Vanysek, P. Chemical properties of materials. In CRC Materials Science and Engineering Handbook, 3rd ed.; Shackelford, J.F., Alexander, W., Eds.; CRC Press: Boca Raton, FL, USA, 2000.

44. Lynch, C.T. Thermodynamic and kinetic data. In CRC Materials Science and Engineering Handbook, 3rd ed.; Shackelford, J.F., Alexander, W., Eds.; CRC Press: Boca Raton, FL, USA, 2000.

45. Minagar, S.; Berndt, C.C.; Gengenbach, T.; Wen, C. Fabrication and characterization of $\mathrm{TiO}_{2}-\mathrm{ZrO}_{2}-\mathrm{ZrTiO}_{4}$ nanotubes on $\mathrm{TiZr}$ alloy manufactured via anodization. J. Mater. Chem. B 2014, 2, 71-83. 
46. Yasuda, K.; MacAk, J.M.; Berger, S.; Ghicov, A.; Schmuki, P. Mechanistic aspects of the self-organization process for oxide nanotube formation on valve metals. J. Electrochem. Soc. 2007, 154, C472-C478.

47. Guidance on the Measurement of Wettability of Insulator Surfaces; SAI Global: Sydney, NSW, Australia, 2005; p. 15.

48. Kokubo, T. Apatite formation on surfaces of ceramics, metals and polymers in body environment. Acta Mater. 1998, 46, 2519-2527.

49. Kim, H.M.; Himeno, T.; Kawashita, M.; Kokubo, T.; Nakamura, T. The mechanism of biomineralization of bone-like apatite on synthetic hydroxyapatite: An in vitro assessment. J. Royal Soc. Interface 2004, 1, 17-22.

50. Ma, Q.; Li, M.; Hu, Z.; Chen, Q.; Hu, W. Enhancement of the bioactivity of titanium oxide nanotubes by precalcification. Mater. Lett. 2008, 62, 3035-3038.

51. Kunze, J.; Muller, L.; Macak, J.; Greil, P.; Schmuki, P.; Muller, F. Time-dependent growth of biomimetic apatite on anodic $\mathrm{TiO}_{2}$ nanotubes. Electrochim. Acta 2008, 53, 6995-7003.

52. Kosmulski, M. Points of zero charge. In Chemical Properties of Material Surfaces; Hubbard, A.T., Ed.; CRC Press: New York, NY, USA, 2001; pp. 731-744.

53. Kosmulski, M. Surface charging in absence of strongly adsorbing species. In Chemical Properties of Material Surfaces; Hubbard, A.T., Ed.; CRC Press: New York, NY, USA, 2001; pp. 65-309.

54. Gadelmawla, E.S.; Koura, M.M.; Maksoud, T.M.A.; Elewa, I.M.; Soliman, H.H. Roughness parameters. J. Mater. Process. Technol. 2002, 123, 133-145.

55. Owens, D.K.; Wendt, R.C. Estimation of the surface free energy of polymers. J. Appl. Polym. Sci. 1969, 13, 1741-1747.

56. Dann, J.R. Forces involved in the adhesive process. I. Critical surface tensions of polymeric solids as determined with polar liquids. J. Colloid Interface Sci. 1970, 32, 302-320.

57. Oyane, A.; Onuma, K.; Ito, A.; Kim, H.M.; Kokubo, T.; Nakamura, T. Formation and growth of clusters in conventional and new kinds of simulated body fluids. J. Biomed. Mater. Res. A 2003, 64, 339-348.

(C) 2015 by the authors; licensee MDPI, Basel, Switzerland. This article is an open access article distributed under the terms and conditions of the Creative Commons Attribution license (http://creativecommons.org/licenses/by/4.0/). 